\title{
A Phylogenetic Analysis of Otters (Lutra lutra) Inhabiting in the Gyeongnam Area Using D-Loop Sequence of mtDNA and Microsatellite Markers
}

\author{
Moon-Sung Park ${ }^{1}$, Hyun-Tae Lim ${ }^{1}$, Ki-Cheol Oh², Young-Rok Moon ${ }^{3}$, Jong-Gap Kim ${ }^{1}$ and \\ Jin-Tae Jeon ${ }^{1} *$ \\ ${ }^{1}$ Division of Applied Life Science (BK21 program) Graduate School of Gyeongsang National University, Jinju 660-701, Korea \\ ${ }^{2}$ Nakdong River Valley Ministry of Environment, Changwon 641-722, Korea \\ ${ }^{3}$ Otters Ecology Research Center, Jinju 660-991, Korea
}

Received November 19, 2010/Accepted January 31, 2011

\begin{abstract}
The otter (Lutra lutra) in Korea is classified as a first grade endangered species and is managed under state control. We performed a phylogenetic analysis of the otter that inhabits the Changnyeong, Jinju, and Geoje areas in Gyeongsangnamdo, Korea using mtDNA and microsatellite (MS) markers. As a result of the analysis using the 676-bp D-loop sequence of mtDNA, six haplotypes were estimated from five single nucleotide polymorphisms. The genetic distance between the Jinju and Geoje areas was greater than distances within the areas, and the distance between Jinju and Geoje was especially clear. From the phylogenetic tree estimated using the Bayesian Markov chain Monte Carlo analysis by the MrBays program, two subgroups, one containing samples from Jinju and the other containing samples from the Changnyeong and Geoje areas were clearly identified. The result of a parsimonious median-joining network analysis also showed two clear subgroups, supporting the result of the phylogenetic analysis. On the other hand, in the consensus tree estimated using the genetic distances estimated from the genotypes of 13 MS markers, there were clear two subgroups, one containing samples from the Jinju, Geoje and Changnyeong areas and the other containing samples from only the Jinju area. The samples were not identically classified into each subgroup defined by mtDNA and MS markers. It could be inferred that the differential classification of samples by the two different marker systems was because of the different characteristics of the marker systems used, that is, the mtDNA was for detecting maternal lineage and the MS markers were for estimating autosomal genetic distances. Nonetheless, the results from the two marker systems showed that there has been a progressive genetic fixation according to the habitats of the otters. Further analyses using not only newly developed MS markers that will possess more analytical power but also the whole mtDNA are needed. Expansion of the phylogenetic analysis using otter samples collected from the major habitats in Korea should be helpful in scientifically and efficiently maintaining and preserving them.
\end{abstract}

Key words : Otter, Gyeongsangnamdo, mtDNA, microsatellite, phylogenetic analysis

\section{서 론}

수달은 족제비, 오소리, 담비 등과 같은 식육목 족제비과에 속해 수달아과로 분류되는 동물이며, 초기 학자들에 의해 19 종 63아종으로 보고된 바 있으나, 1987년 Van 등[34]에 의해 새로운 수달 종을 Lontra속에서 Lutra종으로 분리시켰다. $\mathrm{IUCN} / \mathrm{SSC}$ 에 보고된 Otter Identification Sheets에 따르면, 수 달은 세계적으로 총 13 종으로 분류되어 있고, 그 중 국내에 서식하는 수달은 Eurasian otter (Lutra lutra) 1종뿐이다[28]. 하지만 모피를 목적으로 한 지나친 사냥과 수질오염 및 서식 지 파괴 등으로 인해 그 수가 급감하여 현재 남한에 서식하는 수달(Lutra lutra)은 1982년 천연기념물 제330호와 2005년 멸종

*Corresponding author

Tel : +82-55-751-5516, Fax : +82-55-756-7171

E-mail: jtjeon@gnu.ac.kr
위기야생동물 I 급으로 지정되었으며[16], 국제적으로는 IUCN (International Union for the Conservation of Nature)이 발행 한 Red Data Book에 등재되어 있으며, CITES (Convention on International Trade in Endangered Species of wild fauna and flora)의 부속서 I 에 포함되어 멸종위기에 처한 종으로 규정하고 상업적 목적을 위한 국제거래를 금지하고 있다 [8,13]. 또한 야생동물로서, 내륙지역 수 환경생태계 먹이사슬 의 최상위층에 해당되며, 하천생태계의 건강도를 나타내는 지 표 종으로 중요한 위치에 있다.

국외의 경우 수달에 대한 다양한 복원계획이 이루어지고 있는데, 영국에서는 20 년 이상의 과학적인 복원노력의 결과 현재 각 지역 개체군의 크기가 안정적이거나 증가하는 추세에 있으며[15], 지중해 연안의 스페인, 포르투갈, 그리스 등지에서 도 지속적인 복원 노력을 통해 안정적인 개체군을 유지하고 있다고 보고되어 있다[24]. 
일반적으로 DNA marker를 이용한 개체의 유전적 다형성 및 집단 내 유전적 다양성 분석에 microsatellite (MS) marker 와 mitochondrial DNA (mtDNA)가 많이 활용되고 있다. 척추 동물에서 mitochondrial 유전체 서열의 총 길이는 종마다 약 간의 차이는 있으나 대략 $16,000 \sim 17,000 \mathrm{bp}$ 로서 국내 수달의 경우 $\mathrm{mtDNA}$ 의 전체 길이 $16,505 \mathrm{bp}$ 이며, 2 개 $\mathrm{rRNAs}, 22$ 개 tRNAs, 13개 protein-coding genes (PCGs), 하나의 control region $(\mathrm{CR})$ 로 이루어져 있다. 이 중 D-loop영역은 타 유전자에 비해 진화속도가 빠르기 때문에 모계이동에 대한 추정을 위해 계통분류 연구와 종마다 고유의 특이 서열이 반복성을 갖는 tandem repeat를 갖고 있어 종을 식별하는데 중요한 marker 로서 이용되고 있다[7,17].

Mitochondrial 유전체를 이용하여 척추동물간의 계통관계 와 진화를 밝히려는 노력이 부단히 이루어지고 있는데, 이는 mitochondrial 유전체의 크기가 작고, 추출이 쉽다는 이유 외 에 몇 가지 장점을 가지고 있기 때문이다. 첫째, mitochondrial 는 모계유전이고[20], 두 번째는 다른 mitochondrial와 $\mathrm{re}^{-}$ combination 한다는 증거가 없다[9,12]. 그 의미는 척추동물의 mitochondrial가 동종 간의 recombination 없이 모계를 통해 전해지므로 핵 유전자에 비해 mitochondrial 분자의 진화 역 사가 좀 더 간단하다는 뜻이다. 1990년 Kondo 등[18]은 Drosophila에서 mitochondrial가 부모에게서 유전되는 경우를 보여주었으나, 이것이 종 내에서의 교차를 의미하지는 않는 다. 세 번째로 mitochondrial는 repair system의 결여에 의해 핵 유전자에 비례해서 빠르게 진화하고 있다는 것이다[4].

그리고 MS marker의 경우 다형성이 매우 높아 많은 유전체 정보를 제공해주며, 실험상의 용이성 등이 좋아 동물 집단의 유전적 다양성 분석 등에 사용되고 있다[21]. 종을 보전, 관리 하기 위해서는 그 지역에 서식하는 개체군의 크기를 정확히 파악하는 것이 우선적으로 수행되어야 한다. 지금까지의 방법 은 장기적인 생태학적 모니터링을 통해 배설물의 수와 빈도 등의 분석을 통해 개체군의 크기를 추정하는 방법을 사용하였 으나 이러한 추정방법은 실제 개체군의 크기와 많은 차이가 있고 개체군의 관리를 위한 자료로 활용하는데 많은 문제점이 제기되었다[19,24].

따라서 본 연구는 진주인근지역과 거제도, 창녕 우포늪 지 역에서 서식하고 있는 수달 집단을 대상으로 조직과 분변을 이용하여, MS marker와 mtDNA 분석을 통해 개체군 내의 유전적 다양성을 기초로 개체군의 크기, 계통 유전학적 유연 관계 등의 종에 대한 생물학적 자료를 제공하기 위하여 수행 하였다.

\section{재료 및 방법}

\section{공시동물 및 DNA 추출}

본 연구에 사용한 25 개의 수달 시료는 (사)수달생태연구센
터의 도움으로 경남의 수달 주요 서식지인 진주 진양호, 창녕 우포늪, 거제해변지역을 대상으로 수집하였다. 진주 인근 국 도에서 Road-Kill 된 수달 사체에서 채취한 9개의 조직시료 (Lutra_01부터 09까지)와 창녕 우포늪 인근지역에서 RoadKill 된 수달 사체에서 채취한 1개의 조직(Lutra_10) 그리고 진주인근 지역(진양호)에서 채취한 분변시료 8개(Lutra_11부 터 18 까지)와 거제지역에서 채취한 분변시료 7개(Lutra_19부 터 25까지)로 구성되어 있으며, 조직 시료의 경우 proteinase $\mathrm{K} / \mathrm{phenol} /$ chloroform/isoamylalcohol 방법으로 Genomic $\mathrm{DNA}$ 를 추출하였으며, 분변 시료의 경우 Genomic DNA 추출 KIT (iNtRON. Korea)를 이용하여 Genomic DNA를 추출해 $\mathrm{mtDNA}$ 분석 및 $\mathrm{MS}$ marker 분석을 수행하였다.

\section{mtDNA D-loop PCR 증폭}

국내에 서식하고 있는 수달을 대상으로 mtDNA의 $\mathrm{D}-\mathrm{loop}$ 지역에 관한 연구가 전무하여 국외의 선진 연구자들이 연구한 결과를 기초로 국내 수달에 적용 가능한 primer를 선발하였 다. 2008년 Centrón 등[6]이 남미에서 서식하는 Southern river otter (Lontra provocax)를 대상으로 연구한 결과(NCBI: $\mathrm{DQ} 368686$ )를 기초로 1 쌍의 primer (CR F 5'-GAC GTG TAC CTC TTC TCG-3', CR R 5'-CTA TAG GTA TTT GTA TAC TTT TG-3')를 제작하였다. 제작한 primer가 국내에서 서식하 는 수달에도 적용이 가능한지 검증하기 위해 Gradient PCR (MJ Research, USA)을 이용하여 $50^{\sim} 65^{\circ} \mathrm{C}$ 까지 annealing 온도 를 설정하여 $\mathrm{DNA}$ 증폭 여부를 검증하였다.

검증 후 $\mathrm{PCR}$ 증폭은 Genomic DNA $1 \mu \mathrm{l}$ (조직시료의 경우 $50 \mathrm{ng} / \mathrm{\mu l}$, 분변시료의 경우 $100 \mathrm{ng} / \mathrm{\mu l})$, primer 각각 $1 \mu \mathrm{l}(10$ $\mathrm{pmol} / \mathrm{\mu l}$ ), Taq DNA polymerase (TaKaRa, Japan) $0.1 \mu \mathrm{l}, 10 \times$ buffer $2.5 \mu \mathrm{l}, 0.25 \mathrm{mM} \mathrm{dNTP} 2 \mu \mathrm{l}$ 에 증류수를 첨가하여 최종 $25 \mu 1$ 용량으로 반응하였다. PCR 조건은 $95^{\circ} \mathrm{C}$ 에서 5 분간 $\mathrm{de}^{-}$ naturation을 실시한 후, $94^{\circ} \mathrm{C}$ 에서 1 분, $56^{\circ} \mathrm{C}$ 에서 1 분, $72^{\circ} \mathrm{C}$ 에 서 1 분을 $1 \mathrm{cycle}$ 로 하여 35 회 반복한 후, $72^{\circ} \mathrm{C}$ 에서 5 분간 $\mathrm{ex}^{-}$ tension하고 $8^{\circ} \mathrm{C}$ 에서 보관하였다. $\mathrm{PCR}$ 산물은 $1.5 \%$ agarose gel 상에서 전기영동 확인하였다.

\section{염기서열 결정 및 다중정렬}

수달 $\mathrm{mtDNA} \mathrm{D}$-loop 서열 결정은 $\mathrm{ABI} 3130$ xl $\mathrm{DNA}$ Sequencer (Applied Biosystems, USA)를 이용하여 direct sequencing을 수행하였다. 유전자간의 경계영역 설정은 2009년 $\mathrm{Ki}$ 등[17]이 보고한 염기서열에 준하여 D-loop 염기서열 시작 과 끝 위치를 결정하였다.

\section{MS marker분석}

본 연구에서 이용한 $\mathrm{MS}$ marker는 북미지역의 강에서 서식 하는 Lontra canadensis를 대상으로 2004년과 2005년 Amanda 등[2,3]이 제안한 20종의 MS marker 중 국내 서식하는 수달에 
적합한 13종을 선발하여(Table 1), 조직 시료의 경우 Multiplex $\mathrm{PCR}$ 방법을 이용하여 분석하였으며, 분변 시료의 경우 증폭 이 잘 이루어 지지 않아 1 차 $\mathrm{PCR}$ 을 해서 나온 $\mathrm{PCR}$ 산물을 이용하여 2차 $\mathrm{PCR}$ 을 한 후에 $\mathrm{MS}$ 분석을 실시하였다.

조직 시료를 이용한 Multiplex PCR 증폭은 Genomic DNA

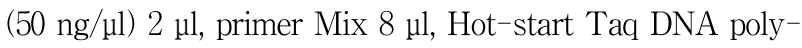
merase (Bioneer, Korea) $0.4 \mu \mathrm{l}, 10 \times$ buffer $1.5 \mu \mathrm{l}, 0.25 \mathrm{mM}$ $\mathrm{dNTP} 1.2 \mu \mathrm{l} \mathrm{MgCl} 21.1 \mu \mathrm{l}$, DMSO $0.25 \mu \mathrm{l}$ 의 조성에 증류수를 첨가하여 최종 부피를 $15 \mu 1$ 로 반응 하였으며, $\mathrm{PCR}$ 조건은 $95^{\circ} \mathrm{C}$ 에서 15 분간 denaturation을 실시한 후 $94^{\circ} \mathrm{C}$ 에서 60 초, 5 $8^{\circ} \mathrm{C}$ 에서 75 초 $72^{\circ} \mathrm{C}$ 에서 60 초 $1 \mathrm{cycle}$ 로 하여 4 cycle, $94^{\circ} \mathrm{C}$ 에서 60 초, $57^{\circ} \mathrm{C}$ 에서 75 초 $72^{\circ} \mathrm{C}$ 에서 60 초 1 cycle로 하여 4 cycle, $94^{\circ} \mathrm{C}$ 에서 60 초, $56^{\circ} \mathrm{C}$ 에서 75 초 $72^{\circ} \mathrm{C}$ 에서 60 초 $1 \mathrm{cycle}$ 로 하여 24 cycle을 반복하는 Touch Down PCR 방법을 사용하였다. 그 후 $65^{\circ} \mathrm{C}$ 에서 30 분 extension 후 $8^{\circ} \mathrm{C}$ 에서 종료하였다.

분변 시료를 이용한 1 차 $\mathrm{PCR}$ 의 경우 Genomic DNA (100 $\mathrm{ng} / \mathrm{\mu l}) 1 \mu \mathrm{l}$, primer 각각 $1 \mu \mathrm{l}(10 \mathrm{pmol} / \mathrm{\mu l})$, Taq DNA polymerase (TaKaRa, Japan) $0.1 \mu l, 10 \times$ buffer $1.5 \mu l, 0.25 \mathrm{mM}$ $\mathrm{dNTP} 1.2 \mu \mathrm{l}$ 조성에 증류수를 첨가하여 최종 부피를 $15 \mu \mathrm{l}$ 로
반응 하였으며, $\mathrm{PCR}$ 조건은 $95^{\circ} \mathrm{C}$ 에서 5 분간 $\mathrm{DNA}$ 를 denaturation을 실시한 후, $94^{\circ} \mathrm{C}$ 에서 1 분, $56^{\circ} \mathrm{C}, 51^{\circ} \mathrm{C}, 61^{\circ} \mathrm{C}$ 에서 1 분, $72^{\circ} \mathrm{C}$ 에서 1 분으로 이루어진 합성반응을 30 회 반복한 후, $72^{\circ} \mathrm{C}$ 에서 5 분간 extension하고 $8^{\circ} \mathrm{C}$ 에서 보관하였고, 2 차 $\mathrm{PCR}$ 의 경 우 1차 PCR 산물 $1 \mu \mathrm{l}$, primer 각각 $1 \mu \mathrm{l}(10 \mathrm{pmol} / \mathrm{\mu l})$, Taq DNA polymerase (TaKaRa, Japan) $0.1 \mu l, 10 \times$ buffer $1.5 \mu l$, $0.25 \mathrm{mM}$ dNTP $1.2 \mu \mathrm{l}$ 조성에 증류수를 첨가하여 최종 부피를 $15 \mu \mathrm{l}$ 로 반응 하였으며, $\mathrm{PCR}$ 조건은 $95^{\circ} \mathrm{C}$ 에서 5 분간 $\mathrm{DNA}$ 를 denaturation을 실시한 후, $94^{\circ} \mathrm{C}$ 에서 1 분, $59^{\circ} \mathrm{C}$ 에서 1 분, $72^{\circ} \mathrm{C}$ 에서 1 분으로 이루어진 합성반응을 30 회 반복한 후, $72^{\circ} \mathrm{C}$ 에서 5 분간 extension하고 $8^{\circ} \mathrm{C}$ 에서 보관하였다. 대립유전자형분석 은 ABI3130x/ DNA Sequencer (Applied Biosystems, USA)를 사용하여 전기영동을 수행하였으며, GeneMapper version 4.0 (Applied Biosystems, USA)를 이용하여 크기 및 표식자의 종 류별로 분류한 후 Microsoft Excel (Microsoft, USA)을 이용하 여 자료를 취합하였다.

\section{계통유전학적 분석}

수달 D-loop 염기서열 다중정렬은 CLUSTAL W program

Table 1. Characteristics of 13 microsatellite markers in the 25 otters (Lutra lutra) used in this study

\begin{tabular}{|c|c|c|c|c|c|c|c|c|c|}
\hline Name & $\begin{array}{c}\text { GenBank } \\
\text { Accession No. }\end{array}$ & Lable & $\begin{array}{c}\text { PCR } \\
\text { product(bp) }\end{array}$ & $\begin{array}{l}\text { No. of } \\
\text { alleles }\end{array}$ & $N$ & $\mathrm{He}$ & PIC & $\begin{array}{l}\text { Hardy-Weinberg } \\
\text { equilibrium } \\
(P \text {-value })\end{array}$ & $5^{\prime}$-Primer Sequence-3' \\
\hline RIO_18 & AY833269 & FAM & $140-165$ & 2 & 25 & 0.719 & 0.640 & $\mathrm{ND}^{1)}$ & $\begin{array}{l}\text { F TTC CAT TGT CTC TTG GCT TG } \\
\text { R GTT TCT CCC TCT CCA CAC TTG TGC TC }\end{array}$ \\
\hline RIO_08 & AY268058 & FAM & 204-214 & 2 & 23 & 0.471 & 0.346 & $\mathrm{ND}^{1)}$ & $\begin{array}{l}\text { F } \text { TTT CCA GAG CCA ATT TGT CA } \\
\text { R CTT GCC TGC TGA CAT TGA AG }\end{array}$ \\
\hline RIO_01 & AY268051 & FAM & $264-280$ & 2 & 25 & 0.383 & 0.305 & $\mathrm{ND}^{1)}$ & $\begin{array}{l}\text { F } \text { AAG GGC ACC TCG AGA CAA T } \\
\text { R } \\
\text { CAT GCT TGA CCT TGA GCA AC }\end{array}$ \\
\hline RIO_11 & AY833262 & VIC & $156-168$ & 3 & 25 & 0.673 & 0.585 & $\mathrm{ND}^{1)}$ & $\begin{array}{l}\text { F TCT TCC ACT TTT CAA TTT AGG TA } \\
\text { R GCC CAA GGT TCA CTA TCA AG }\end{array}$ \\
\hline RIO_02 & AY268052 & VIC & 184-198 & 10 & 25 & 0.875 & 0.841 & $\mathrm{ND}^{1)}$ & $\begin{array}{ll}\text { F } & \text { GTA GAG TGG GGC GCC TAA G } \\
\text { R } & \text { TGT CCT TGG AAG AGA CAT GC }\end{array}$ \\
\hline RIO_04 & AY268054 & VIC & $255-273$ & 5 & 23 & 0.556 & 0.497 & $\mathrm{ND}^{1)}$ & $\begin{array}{l}\text { F CAA GCA CCA ACT CCT CAA T } \\
\text { R CCA CAA GCC AGA TTC CTC TC }\end{array}$ \\
\hline RIO_03 & AY268053 & NED & $194-218$ & 3 & 25 & 0.556 & 0.454 & 0.0001 & $\begin{array}{l}\text { F } \text { ATC AGC CTG AGT CCC TGA AC } \\
\text { R ACA GCC AGA ACC AAA AGA CA }\end{array}$ \\
\hline RIO_10 & AY268060 & NED & $243-259$ & 4 & 25 & 0.558 & 0.493 & $\mathrm{ND}^{1)}$ & $\begin{array}{l}\text { F } \text { CAT TCG TGG ACA TTC GGT AA } \\
\text { R } \quad \text { GGC AAG GAA TCC TGG TTA TG }\end{array}$ \\
\hline RIO_16 & AY833267 & $\mathrm{NED}$ & $266-280$ & 9 & 22 & 0.753 & 0.697 & $\mathrm{ND}^{1)}$ & $\begin{array}{l}\text { F } \text { GGT GCT TCT TAA GGA ACT GAG C } \\
\text { R ATT TAT TGG GCA TGG AAG CA }\end{array}$ \\
\hline RIO_07 & AY268057 & PET & $167-177$ & 1 & 25 & 0.000 & 0.000 & $\mathrm{ND}^{1)}$ & $\begin{array}{l}\text { F AAG CAC TTC CAG ATA TCA GTT GC } \\
\text { R CCC AAC TTG AGT GGG ACT TT }\end{array}$ \\
\hline RIO_12 & AY833262 & PET & $207-213$ & 3 & 25 & 0.153 & 0.145 & $\mathrm{ND}^{1)}$ & $\begin{array}{l}\text { F } \text { GTA TCG TCC AGG CTG CTC TC } \\
\text { R CCA CAG CCA GCT CTG AAT AA }\end{array}$ \\
\hline RIO_15 & AY833266 & PET & $253-261$ & 2 & 25 & 0.327 & 0.269 & $\mathrm{ND}^{1)}$ & $\begin{array}{ll}\text { F } & \text { AGT GCA CAG TGG TGG TCT TG } \\
\text { R } & \text { TCC TGA TTC TGC TTG GTT CA }\end{array}$ \\
\hline RIO_19 & AY833270 & PET & $273-285$ & 5 & 24 & 0.719 & 0.640 & $\mathrm{ND}^{1)}$ & $\begin{array}{l}\text { F GGT CCC AGG TGC AAA TCT TA } \\
\text { R GAT TTG GGT CTT CCA ATG GTT }\end{array}$ \\
\hline
\end{tabular}

1) NA: not analysis 
[32]을 이용하였고, Fasta format과 Nexus format 간 Data 전 환은 DAMBE [33]와 DnaSP 4.50 .3 [22]로 수행하였다. 최적의 분석 모델 설정은 MrModeltest 2.3 [27,30]을 수행한 후 $\mathrm{PAUP} * 4.0$ [31]에서 분석하였다. 계통수 작성은 MRBAYES 3.1 [29]을 이용해 3,500,000번 반복 수행하여, FigTree v1.3.1을 이용해 도식화 하였다. 국내 수달 사이의 haplotype 연관관계 분석은 parsimony consensus NJ tree method를 이용하여 계 통수 작성과 분석에 이용하였다.

MS data를 이용한 계통유전분석은 MSA (Microsatellite analyzer) version 3.15 program [10]을 이용하여 유전력을 산 출하였고, 산출된 유전력을 바탕으로 PHYLIP v3.6 package program의 pitch program을 활용하여 유전적 거리를 계산해, consense program을 이용하여 tree를 완성하였으며, MS marker의 heterozygosity (He)와 polymorphic information content (PIC), 그리고 Hardy-Weinberg equilibrium (HWE)은 Cervus version 2.0 [23]을 이용하여 추정하였다.

\section{결과 및 고찰}

국내에 서식하는 수달 25 개체의 시료를 이용하여 $\mathrm{mtDNA}$ D-loop 전체 $1,087 \mathrm{bp}$ [17] 중에 $676 \mathrm{bp}$ 의 부분의 염기서열을 분석하여 CLUSTAL W program [32]을 이용해 multi-alignment를 수행한 결과 5 개 지역에서 단염기다형성(single nucleotide polymorphism, SNP)이 확인되었으며, 총 6개의 haplotype으로 구분되었으며, 거제도에서 수집한 시료 7 개의 경
우 모두 동일한 haplotype을 나타내었으며, 진주인근지역에 서 수집한 시료의 경우 5 개의 haplotype이 관찰 되었다. 그 중 진주인근지역에서 수집한 시료 중 Lutra_18과 창녕 우포늪 에서 수집한 시료 Lutra_10의 경우 거제도 지역에서 수집한 시료들과 동일한 haplotype을 나타내었다(Table 2).

또한 진주인근지역에서 수집한 17 개의 시료에서 5 개의 $\mathrm{SNP}$ 가 관찰되었고 거제와 창녕지역에서 수집한 8개의 시료에 서는 SNP가 발견되지 않았다(Table 3). 이는 2004년 Cho 등[7] 이 연구한 한반도 야생멧돼지 결과와 비교해보면 한반도 야생 멧돼지의 경우 9 마리의 mtDNA D-loop 영역 중 일부인 477 $\mathrm{bp}$ 를 분석한 결과 10 개의 $\mathrm{SNP}$ 가 관찰되어 본 연구에서 사용 한 공시동물의 개체 수 보다 적은 공시동물과 짧은 D-loop 영역의 염기서열을 분석한 결과 임에도 불구하고 수달보다 다양한 SNP가 관찰 되었다는 것은 국내에 서식하는 수달이 다른 야생 동물에 비해 유전적 다양성은 낮고, 서식하는 개체 의 수가 적다는 것으로 사료되어 진다. 특히, 거제와 창녕지역 에 서식하는 수달에서는 $\mathrm{SNP}$ 이 전혀 관찰되지 않고 모든 개체 들이 동일한 haplotype으로 추정되었으며, 이런 점은 거제와 창녕지역의 수달들이 아주 제한된 두수의 모계에서 유래되었 음을 의미한다. 이로 인하여 높은 근친도를 유지하고 있을 가 능성이 있음을 의미한다고 사료되며, 이 지역 수달이 자연상 태에서 지속 가능한 집단을 유지하는데 있어 중대한 위해 요 소로 작용할 가능성이 있다. 따라서, 보다 면밀한 모계라인의 분석을 위하여 $\mathrm{mtDNA}$ 의 전체 지역을 이용한 추가 분석을 반드시 수행하여, 위해 요소에 대한 보다 정확한 조사분석 및

Table 2. The five haplotypes estimated in 25 otters using the mtDNA D-loop

\begin{tabular}{|c|c|c|c|c|c|c|c|}
\hline \multirow{2}{*}{ Haplotype } & \multirow{2}{*}{$\begin{array}{l}\text { No. of } \\
\text { frequencies }\end{array}$} & \multicolumn{5}{|c|}{$\begin{array}{l}\text { Nucleotide position in } \\
\text { D-loop sequence }\end{array}$} & \multirow{2}{*}{ Sample name } \\
\hline & & 405 & 449 & 471 & 493 & 559 & \\
\hline Haplotype 01 & 6 & $\mathrm{C}$ & $\mathrm{C}$ & $\mathrm{C}$ & $\mathrm{C}$ & $\mathrm{T}$ & Lutra_04, Lutra_06, Lutra_12, Lutra_13, Lutra_14, Lutra_15 \\
\hline Haplotype 02 & 2 & $\mathrm{C}$ & $\mathrm{T}$ & $\mathrm{C}$ & $\mathrm{C}$ & $\mathrm{T}$ & Lutra_07, Lutra_11 \\
\hline Haplotype 03 & 5 & $\mathrm{C}$ & $\mathrm{C}$ & $\mathrm{T}$ & $\mathrm{C}$ & $\mathrm{T}$ & Lutra_03, Lutra_05, Lutra_08, Lutra_09, Lutra_17 \\
\hline Haplotype 04 & 1 & $\mathrm{C}$ & $\mathrm{C}$ & $\mathrm{C}$ & $\mathrm{T}$ & $\mathrm{T}$ & Lutra_16 \\
\hline Haplotype 05 & 2 & $\mathrm{C}$ & $\mathrm{C}$ & $\mathrm{T}$ & $\mathrm{T}$ & $\mathrm{T}$ & Lutra_01, Lutra_02 \\
\hline Haplotype 06 & 9 & $\mathrm{~T}$ & $\mathrm{C}$ & $\mathrm{T}$ & $\mathrm{T}$ & C & $\begin{array}{l}\text { Lutra_10, Lutra_18, Lutra_19, Lutra_20, Lutra_21, Lutra_22, } \\
\text { Lutra_23, Lutra_24, Lutra_25 }\end{array}$ \\
\hline
\end{tabular}

Table 3. Summary of phylogenetic variation and relationships between otters in Jinju and Geoje Island/Changnyeong

\begin{tabular}{lccc}
\hline & Jinju & Geoje Island / Changnyeong & Total \\
\hline No. of sequence & 17 & 8 & 25 \\
Variable sites $^{\mathrm{a}}$ & 5 & 0 & 5 \\
Nucleotide diversity $(\pi)^{\mathrm{b}}$ & 0.002 & 0.000 & \\
Nucleotode difference $(\kappa)^{\mathrm{c}}$ & 1.368 & 0.000 & \\
\hline
\end{tabular}

${ }^{\mathrm{a}}$ Variable sites are single nucleotide polymorphism (SNP).

${ }^{b}$ Nucleotide diversity $\left(\times 10^{-3}\right)$ was calculated using only SNPS.

${ }^{\mathrm{c}}$ Average number of nucleotide differences between haplotypes within a haplogroup. 
대책이 반드시 필요한 것으로 사료된다.

분석된 haplotype을 기초로 parsimony consensus NJ tree method를 이용하여 계통수를 작성한 결과 크게 3 개의 그룹으 로 분류가 되며, 진주인근지역에서 수집한 시료가 두 개의 그 룹으로 분류되고, 거제도 지역은 하나의 그룹으로 분류되는 것을 확인 할 수 있었다. 창녕 우포늪 지역에서 수집한 시료의 경우 거제도 그룹과 가까운 유연관계를 나타났으며, 거제도
그룹과 진주인근지역 그룹 간에는 유전적 차이가 있는 것으로 판단되며(Fig. 1A), Haplotype 을 NETWORK 4.5.1.6 Program [5]을 사용하여 도식화한 결과 대부분이 거제도 지역에서 수집 한 시료들이 포함된 haplotype 06 그룹과 진주인근지역에서 수집된 시료 그룹인 haplotype 02 그룹이 가장 먼 유연관계를 나타내었으며, 진주인근지역에서 수집한 시료들로 구성된 haplotype 01, 02, 03, 04, 05 그룹은 가까운 유연관계를 나타내

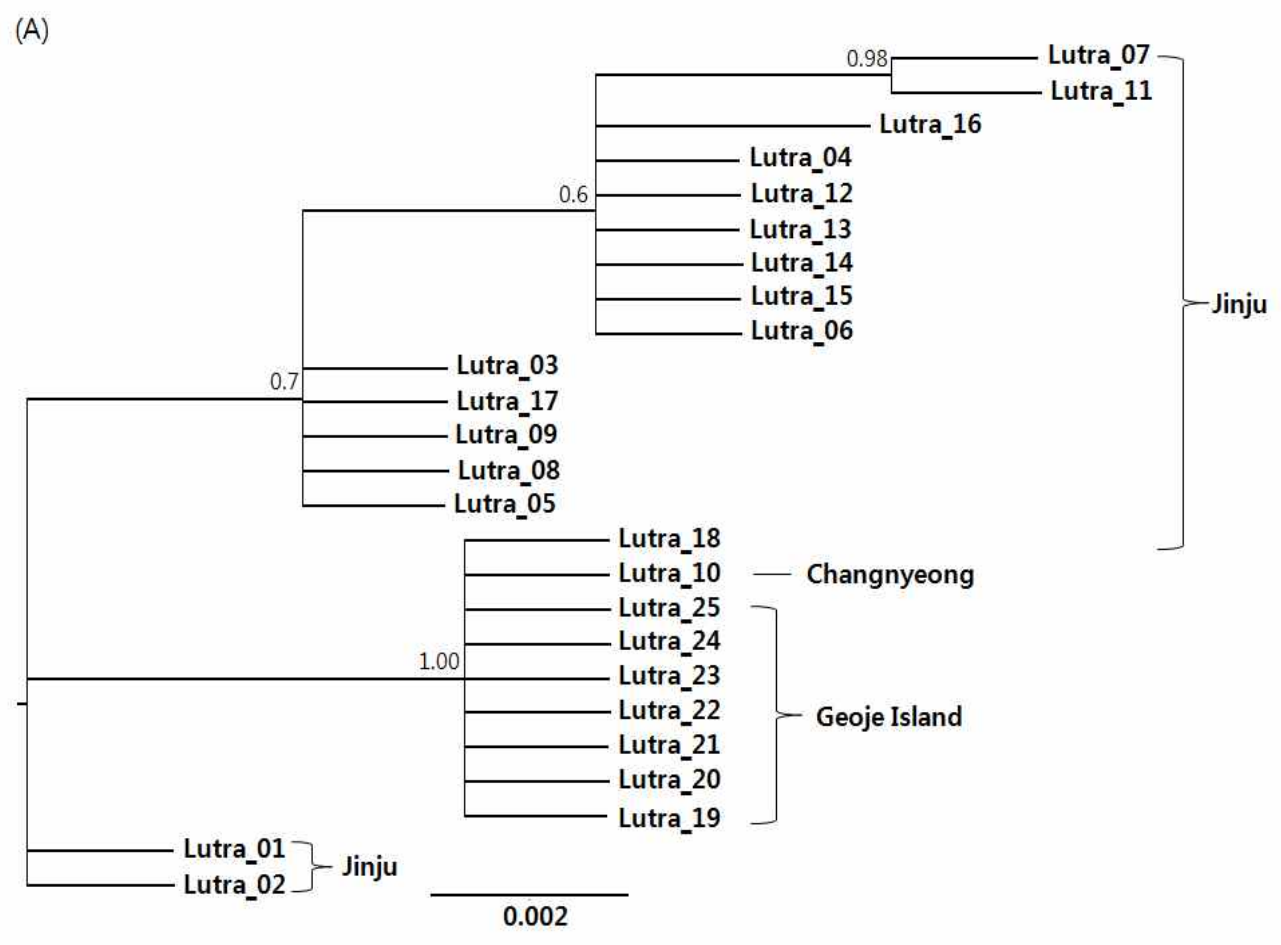

(B)

Jinju

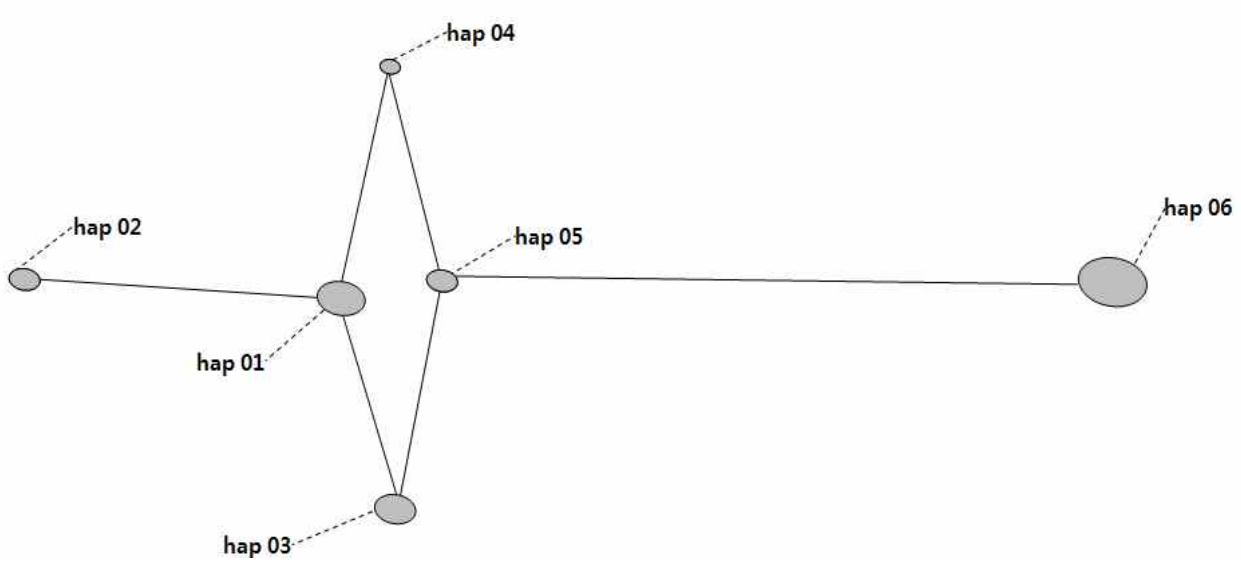

Fig. 1. (A) A consensus phylogenetic tree reconstructed using the statistics for the taxon bipartitions and clade credibility (posterior probability) values. The Bayesian Markov chain Monte Carlo analysis was run with the Hasegawa-Kishino-Yano (HKY) [11] model and (B) A parsimonious median-joining network using selected individuals that shared identical haplotypes with those of 25 otters. 
는 것을 확인 할 수 있었다(Fig. 1B). 이러한 결과들을 종합 해볼 때 진주인근지역에서 수집한 시료의 경우 2 개 이상의 모계집단으로부터 형성 되었고, 거제도 지역에서 수집한 시료 의 경우 1 개 이상의 모계집단으로부터 형성된 것으로 사료되 어 진다.

13종의 MS marker를 이용한 대립유전자형 분석의 경우 조 직 시료의 경우 양질의 Genomic DNA 추출이 용이해 13 종의 MS marker를 한번에 PCR 증폭 할 수 있는 Multiplex PCR 방법을 이용하였으나, 분변 시료의 경우 조직이나 혈액에 비 해 양질의 Genomic DNA 추출이 힘들어 MS marker 외부 서열지역을 1차 PCR한 후 1차 $\mathrm{PCR}$ 산물을 이용하여 2차 $\mathrm{PCR}$ 을 통해 대립유전자형을 분석하였으며, 분석된 대립유전자형 을 바탕으로 marker별 allele 분포와 다형성지수( $H e$ 와 PIC)를 CERVUS version 2.0 program [23]을 이용하여 분석한 결과 총 51 개의 대립유전자형이 나타났으며, 그 중 RIO_02에서는 10 개의 대립유전자형이 나타나 가장 많은 종류의 대립유전자 형을 보였으며, RIO_07에서는 1개의 대립유전자형으로 고정 되어 있는 것으로 나타났고, RIO_07을 제외한 marker들의 $H e$ 및 PIC 추정치는 가장 많은 대립유전자형을 보인 RIO_02에서 0.875 와 0.841 로 나타났고, 3 개의 대립유전자형을 나타낸 RIO_12의 $H e$ 및 $P I C$ 추정치가 각각 0.153 과 0.145 로 가장 낮은 것으로 추정되었다. 이는 RIO_12에서 출현하는 3개의 대립유 전자형에서 분석 시료 모두가 homozygote 형태로 고정되어 나타나는 것이 주된 원인으로 추정되었다. MS marker에 대한 $\mathrm{HWE}$ 검증 결과 13 종의 $\mathrm{MS}$ marker 모두가 분석되지 않거나 위배되는 것으로 나타나 본 연구에서 사용한 MS marker가
국내 수달에 효율성이 낮지만 개체식별 및 친자감별에는 활용 이 가능하나 추가 연구를 통해 국내 수달에 적합한 MS marker 를 발굴하는 연구가 필요하다고 사료되어 진다(Table 1).

그리고 분석된 대립유전자형을 1972년 Nei [26]의 방법을 이용한 $D_{A}$ 유전적 거리지수를 추정하여 Neighbor-joining (NJ) 방법에 의한 계통유연관계 tree를 추정하였으며, Phylip version 3.63을 이용하여 도식화한 결과 크게 2개의 그룹으 로 분류 되었으며, 첫 번째 그룹에는 거제도 지역에서 수집 한 시료들과 진주인근 지역에서 수집한 시료 Lutra_11부터 25 까지 그리고 창녕 우포늪에서 수집한 시료가 하나의 그룹 으로 분류되었으며, 두 번째 그룹에는 진주인근지역에서 수 집한 시료인 Lutra_1부터 9가 하나의 그룹으로 분류되었다. 또한 거제도 지역에서 수집한 시료의 경우 진주인근지역에 서 수집된 시료들 사이에 분류되어 위치하는 것을 확인 할 수 있었다(Fig. 2).

$\mathrm{MS}$ marker의 대립유전자형을 이용한 분석결과가 $\mathrm{mtDNA}$ 를 이용하여 분석한 것과 일부 다른 결과를 보였으나 이런 결과의 차이는 모계를 추정하는 $\mathrm{mtDNA}$ 와 상염색체상의 marker인 MS라는 DNA marker의 특성에 기인한 것으로 보 이나, 경상남도에 서식하는 수달을 크게 진주와 거제지역의 수달로 구분하는 것에는 동일한 결과를 보여 서식지별 유전적 고정현상이 있음을 확인할 수 있었다.

이상의 결과들을 종합해 볼 때 경남지역에서 서식하는 수달 의 경우 각각의 개체별 유전적 다형성은 높지 않고 유전적 거리는 매우 가까운 것으로 사료되며, 거제도와 진주 지역 사 이의 유전적 유연관계의 경우 다소 거리가 있는 것으로 사료

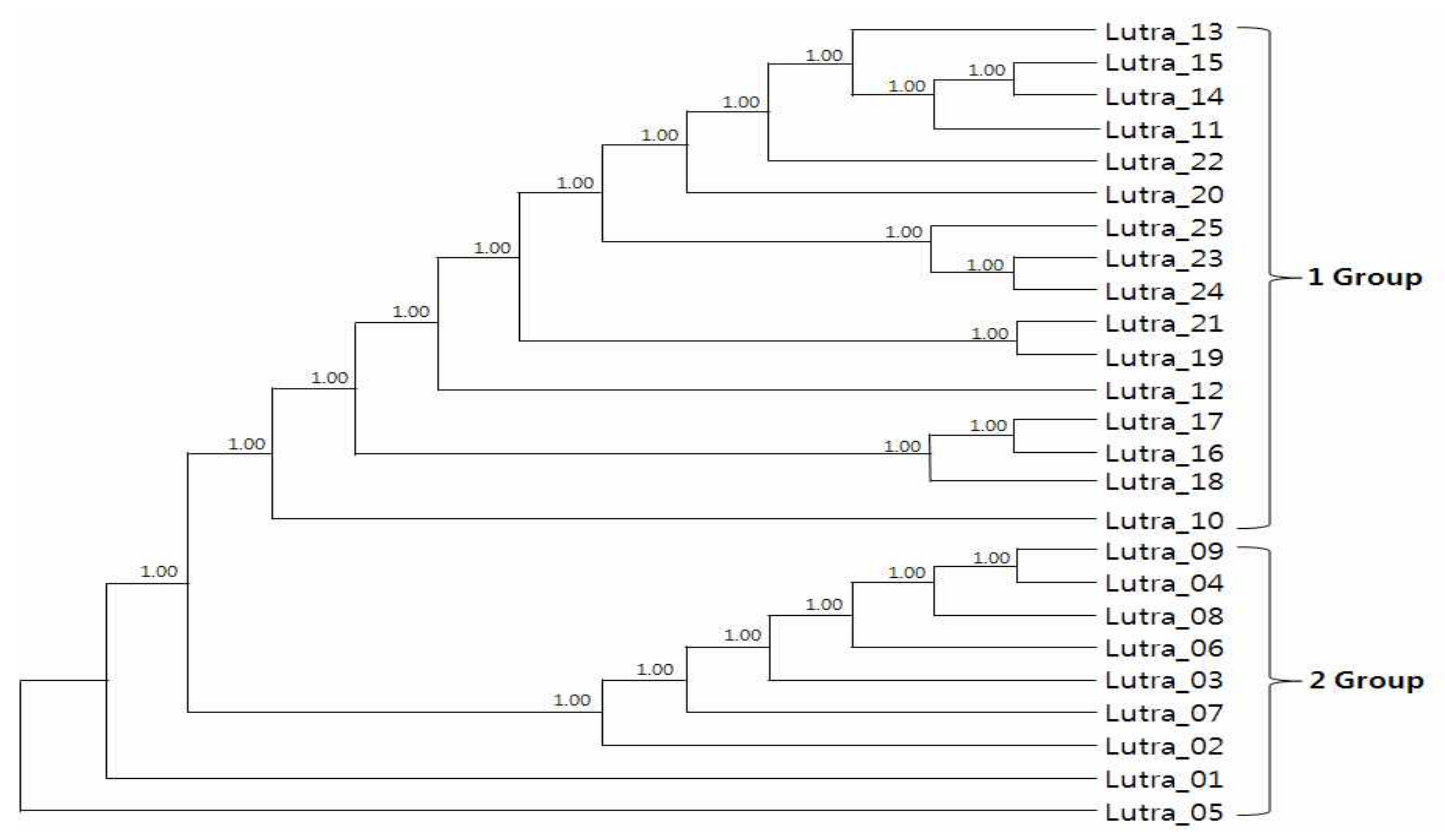

Fig. 2. A neighbor-joining (NJ) tree of genetic relationships among the 25 otters (Lutra lutra) using the $D_{A}$ genetic distance estimated from 13 microsatellite loci. 
되어 진다. 따라서 국내 각 지역에 분포하고 수달의 주요 서식 지를 대상으로 시료를 확보해 $\mathrm{mtDNA}$ 전체 서열 및 $\mathrm{MS}$ mark$\mathrm{er}$ 를 이용한 대립유전자형 분석을 이용한 유전적 유연관계분 석을 실시 할 경우 각 수달의 서식지별 유전적 유연관계에 대한 객관적인 자료가 확보될 것이며, 또한 이를 기반으로 국 내에 서식하는 수달의 개체 수 및 모계 추정 등이 가능하여 천연기념물인 수달의 보전 및 보호에 도움이 될 것으로 사료 되어 진다.

\section{감사의 글}

본 연구에 참여한 대학원생은 교육과학기술부 2단계 BK21 사업의 장학금을 수혜 받았으며, 농림수산식품부 농림기술계 발사업(과제번호: 109177-03-1-SB010)의 지원에 의해 이루어 진 연구결과의 일부이며, 연구비 지원에 감사드립니다.

\section{References}

1. Achmann, R., I. Curik, P. Dovc, T. Kavar, I. Bodo, F. Habe, E. Marti, J. Solkner, and G. Brem. 2004. Microsatellite diversity, population subdivision and gene flow in the Lipizzan horse. Anim. Genet. 35, 285-292.

2. Amanda, S. B., A. F. Jennifer, M. M. Lisa, E. R. Olin Jr, and S. S. Thomas. 2004. Development of polymorphic microsatellite loci for North American river otters (Lontra canadensis) and amplification in related Mustelids. Mol. Ecol. Notes 4, 56-58.

3. Amanda, S. B., A. G. D. Jennifer, E. R. Olin Jr, and S. S. Thomas. 2005. Ten new polymorphic microsatellite loci for North American river otters (Lontra canadensis) and their utility in related Mustelids. Mol. Ecol. Notes 5, 602-604.

4. Brown, W. M., M. George Jr, and A. C. Wilson. 1979. Rapid evolution of animal Mitochondrial DNA. Proc. Natl. Acad. Sci. USA 76, 1967-1971.

5. Bandelt, H. J., P. Forster, and A. Röhl. 1999. Median-joining networks for inferring intraspecific phylogenies. Mol. Diol. Evol. 16, 37-48.

6. Centrón, D., B. Ramirez, L. Fasola, D. W. Macdonald, C. Chehébar, A. Schiavini, and M. H. Cassini. 2008. Diversity of mtDNA in Southern River Otter (Lontra provocax) from Argentinean Patagonia. J. Heredity 99, 198-201.

7. Cho, I. C. 2004. Phylogenetic analysis based on porcine mitochondrial DNA and melanocortin receptor 1 gene: Focusing on Korean Native Pig in Jeju province and Korean Wild Boar. Ph. D Thesis. Gyeongsang National University, Gyeongnam Jinju. Korea

8. CITES. 2005. Appendices I, II and III. (http://www.cites.org/eng/app/appendices.shtml)

9. Clayton, D. A. 1982. Replication of animal Mitochondrial DNA. Cell 28, 693-705.

10. Daniel, D. and S. Christian. 2002. Microsatellite analyser (MSA): a platform independent analysis tool for large mi- crosatellite data sets. Mol. Ecol. Notes 3, 167-169.

11. Hasegawa, M., K. Kishino, and T. Yano. 1985. Dating the human-ape splitting by a molecular clock of mitochondrial DNA. J. Mol. Evol. 22, 160-174.

12. Hayashi, J. I., Y. Tagashira, and M. C. Yoshida. 1985. Absence of extensive recombination between inter- and intraspecies mitochondrial DNA in mammalian cells. Experimental. Cell Res. 160, 387-395.

13. IUCN. 2004. Lutra lutra in the section of the IUCN Red list of threatened species. (www.iucnredlist.org/search/details.php?scecies=12419)

14. Jang, K. H., S. H. Ryu, and U. W. Hwang. 2009. Mitochondrial Genome of the Eurasian Otter (Mamalia, Carnivora, Mustelidae). Genes Genome 31, 19-27.

15. Jessop, R. M. 1993. The re-introduction of the European otter, Lutra Lutra into lowland England carried out by the otter trust, pp. 1983-92: a progress report. in proceeding of the national otter conference (ed. Morris, P. A), the Mammal Society.

16. Jo, Y. S., C. M. Won, and J. P. Kim. 2006. Distribution of Eurasian Otter Lutra lutra in Korea. Korean J. Environ. Biol. 24, 89-94.

17. Ki, J. S., D. S. Hwang, T. J. Park, S. H. Han, and J. S. Lee. 2009. A comparative analysis of the complete mitochondrial genome of the Eurasian otter Lutra lutra (Carnivora; Mustelidae). Mol. Biol. Rep. 37, 1943-1955.

18. Kondo, R., Y. Satta, E. T. Matsuura, H. Isiwa, N. Tagahata, and S. I. Chigusa. 1990. Incomplete maternal transmission Mitochondrial DNA in Drosophila. Genetics 126, 367-379.

19. Kruuk, H. 1995. Wild Otter: Predation and Poulations. Oxford University Press.

20. Lansman, R. A., J. C. Avise, and M. D. Huettel. 1983. Critical experimental test of the domestic cat (Felis catus) Mitochondrial genome and a transposed mtDNA tandem repeat (Numt) in the nuclear genome. Genomics 33, 299-246.

21. Li, K., Y. Chen, C. Moran, B. Fan, S. Zhao, and Z. Peng. 2000. Analysis of diversity and genetic relationships between four Chinese indigenous pig breeds and one Australian commercial pig breed. Anim. Genet. 31, 322-325.

22. Librado, P. and J. Rozas. 2009. DnaSP v5: A software for comprehensive analysis of DNA polymorphism data. Bioinformatics 25, 1451-1452.

23. Marshall, T. C., J. Slate, L. E. B. Kruuk, and J. M. Pemberton. 1998. Statistical confidence for likelihood-based paternity inference in natural populations. Mol. Ecol. 7, 639-655.

24. Mason, C. F. and S. M. Mcdonald. 1986. Otter: Ecology and Conservation. Cambridge University Press.

25. Mason, C. F. and S. M. Mcdonald. 1987. Seasonal Making in an Otter Population. Acta. Theriol. 32, 449-462.

26. Nei, M. 1972. Genetic distance between populations. Am. Nat. 106, 283-292.

27. Nylander, J. A. A. 2004. MrModeltest v2. Program distributed by the author. Evolutionary Biology Centre, Uppsala University. (http://darwin.uvigo.es/software/ modeltest.html)

28. Pat, F. T., S. Macdonald, and C. Mason. 1990. Otters: An 
action plan for their conservation. IUCN/SSC Otter Specialist Group. (http://data.iucn.org/dbtw-wpd/html/ Otter/cover.html)

29. Ronquist, F., and J. P. Huelsenbeck. 2003. MrBayes 3: Bayesian phylogenetic inference under mixed models. Bioinformatics 19, 1572-1574.

30. Posada, D. and K. A. Crandall. 2001. Selecting the best-fit model of nucleotide substitution. Syst. Biol. 50, 580-601.

31. Swofford, D. L. 1998. PAUP*. Phylogenetic Analysis Using Parsimony (*and Other Methods). Version 4. Sinauer Associates, Sunderland, Massachusetts.
32. Thompson, J. D., D. G. Higgins, and T. J. Gibson. 1994. CLUSTAL W: improving the sensitivity of progressive multiple sequence alignment through sequence weighting position specific gap penalties and weight matrix choice. Nucl. Acids Res. 22, 4673-4680.

33. Xia, X. and Z. Xie. 2001. DAMBE: Data analysis in molecular biology and evolution. J. Hered. 92, 371-373.

34. Van, Z. D. J. and C. G. Van. 1987. A phylogenetic study of the Lutrinae (Carnivora; Mustelidae) using morphological data. Can. J. Zool. 65, 2536-544.

\section{초록 : 경남지역 수달(Lutra lutra)의 mitochondrial DNA D-loop지역과 microsatellite marker를 이용한 계통유전학적 유연관계 분석 \\ 박문성 ${ }^{1} \cdot$ 임현태 $^{1} \cdot$ 오기철 ${ }^{2} \cdot$ 문영록 $^{3} \cdot$ 김종갑 $^{1} \cdot$ 전진태 ${ }^{1}$ * \\ ( ${ }^{1}$ 경상대학교 응용생명과학부(BK21), ${ }^{2}$ 낙동강유역환경청, ${ }^{3}$ (사)수달생태연구센터)}

국내에 서식하는 수달의 경우 멸종 위기 I 급 종으로 지정되어 국가적인 차원에서 관리하고 있는 보호종이다. 수달의 유전자원 보호 및 체계적인 관리를 위한 기초자료로 활용하기 위해 경남지역에 서식하는 수달의 계통유 전학적 유연관계를 mtDNA D-loop 지역의 염기서열분석과 $\mathrm{MS}$ marker 분석을 통하여 실시하였다. 그 결과 mtDNA D-loop 지역의 $676 \mathrm{bp}$ 부분만 보았을 때 5 개의 SNP가 확인되었으며, 6 개의 haplotype이 추정되었다. 진주 인근 지역과 거제도 인근 지역에서 수집한 시료는 지역 내 유전적 거리가 지역 간의 유전적 거리보다는 가까운 것을 확인 할 수 있었고, 진주와 거제도 지역 간의 유전적 거리는 확연히 구분이 되었다. $\mathrm{MrBays}$ 의 Bayesian Markov chain Monte Carlo 분석법을 이용하여 추정한 phylogeny 분석결과 뚜렷한 2개 그룹(진주와 거제/창녕 그룹)으로 분류 되었다. Parsimonious median-joining network [5] 분석의 결과 또한 2개의 뚜렷한 그 룹으로 분류되어 phylogeny 분석결과와 일치하는 결과를 보였다. MS marker를 이용하여 추정한 유전적 거리지 수를 활용하여 추정한 consensus tree의 결과 또한 크게 2개의 그룹으로 분류 되며, 첫 번째 그룹에는 거제도지역 시료, 진주인근지역 시료 일부 그리고 창녕 우포늪에서 채취한 시료가 하나의 그룹으로 나뉘어 졌으며, 두 번째 그룹에는 진주인근 지역에서 채취한 시료만이 포함되어 하나의 그룹을 형성하여, $\mathrm{mtDNA}$ 를 이용하여 분석한 것 과 일부 다른 결과를 보였다. 이러한 결과의 차이는 모계를 추정하는 mtDNA와 상염색체 상의 MS marker의 특성에 기인한 것으로 보이나, 경상남도에 서식하는 수달을 크게 진주와 거제지역의 수달로 구분하는 것에는 유 사한 결과를 보여 서식지 별 유전적 고정현상이 있음을 확인할 수 있었다. 하지만 좀 더 정확한 검증을 위해서는 수달의 full mtDNA 분석 및 국내에서 서식하는 수달에 적합한 MS marker발굴을 통한 대립유전자형을 분석하는 추가 연구가 필요하며, 전국 단위의 수달 시료를 확보하여 유전적 유연관계 분석을 실시한다면 한국 내 수달의 보전 및 보호에 도움이 될 것으로 사료되어 진다. 